\title{
Elaboration and Characterization of Alumina-Fluorapatite Composites
}

\author{
Awatef Guidara, Kamel Chaari*, Jamel Bouaziz
}

Laboratory of Industrial Chemistry, National School of Engineering, Sfax, Tunisia.

Email:kamel70tn@yahoo.fr

Received November $26^{\text {th }}, 2010$; received February $20^{\text {th }}, 2011$; accepted February $28^{\text {th }}, 2011$.

\begin{abstract}
Alumina and fluorapatite powder were mixed in a wet medium in order to elaborate biphasic ceramics composites. The effect of fluorapatite addition $(26.5 \mathrm{wt} \%)$ in the densification and the mechanical properties of the alumina matrix were measured. The phase developments have been systematically analysed by scanning electronic microscopy, X-ray diffraction, Infrared spectroscopy and ${ }^{31} \mathrm{P}$ and ${ }^{27} \mathrm{Al}$ magic angle scanning nuclear magnetic resonance. The Brazilian test was used to measure the mechanical resistance of alumina-26.5 wt\% fluorapatite composites. The densification and strength rupture of composites increase versus sintering temperature and holding time. At $1600^{\circ} \mathrm{C}$, the composites densities reached $85 \%$ and the rupture strength was about $22 \mathrm{MPa}$. Also, the composites sintering at $1500^{\circ} \mathrm{C}$ for 5 hours provides samples with similar density and having higher mechanical resistance, above $26 \mathrm{MPa}$. For longer holding times, the mechanical properties were hindered by the exaggerated grain growth and the formation of intragranular porosity. From $1400^{\circ} \mathrm{C}$, the characterization of the alumina-26.5 wt\% fluorapatite composites indicates the formation of calcium aluminates.
\end{abstract}

Keywords: Sintering, Fluorapatite, Alumina, Bioceramics, Composites, Mechanical properties

\section{Introduction}

Calcium phosphate-based materials have attracted considerable interest in orthopedic and dental applications because of their biocompatibility and tight bonding to bone, resulting in the growth of healthy tissue directly onto their surface [1-4]. Among them, fluorapatite (Fap) has been investigated as an alternative biomedical material [5]. This particular apatite was recognized as the most thermally stable compound [6]. Fluorapatite has also been considered as an attractive material for its similarity in structure and composition to bone with the added benefit of fluoride release [7]. In vitro studies have shown that fluorapatite is biocompatible, has a better stability $[8,9]$ and also provides fluoride release at a controlled rate to ensure the formation of a mechanically and functionally strong bone [10]. However, the mechanical properties of fluorapatite and all other calcium phosphates are generally inadequate for many load-carrying applications [11]. These bioceramics have a low density decreasing the mechanical properties [12-17]. Several combinations between calcium phosphate and other compounds have been proposed in order to improve the poor mechanical properties of calcium phosphate $[2,18$ 23].

Alumina $\left(\alpha-\mathrm{Al}_{2} \mathrm{O}_{3}\right)$ was the first bioceramic widely used clinically. It is used in load-bearing hip prostheses and dental implants because of its combination of excellent corrosion resistance, good biocompatibility, high wear resistance and high strength [1].

The aim of this work was to elaborate a dense material having adequate mechanical properties to be used essentially as dental implants. Implants present the quality of auto-protection against caries proliferation [24]. So, the percentage of Fap is chosen to get the same bone rate of fluoride (approximately $26.5 \mathrm{wt} \%$ ). In bone, the fluoride content is approximately $1 \mathrm{wt} \%(10,000 \mathrm{ppm})$ [5]. Fluoride has also been administered in bone to prevent the reduction in bone density associated with osteoporosis even though results are still controversial [25-27]. High fluoride levels may produce some undesired effects, one of which is linked to an increase in bone fractures [28].

This work focuses on preparing biphasic alumina-26.5 $\mathrm{wt} \%$ Fap composites sintered at various temperatures for different times and to characterize the resulting composites with density and mechanical properties. 


\section{Materials and Methods}

The fluorapatite powder was synthesized by a wet-chemical method [29-31]. Analytical grade $\mathrm{Ca}\left(\mathrm{NO}_{3}\right)_{2} \cdot 4 \mathrm{H}_{2} \mathrm{O}$, $\left(\mathrm{NH}_{4}\right) 2 \mathrm{HPO}_{4}$ and $\mathrm{NH}_{4} \mathrm{~F}$ were used as the starting materials. A calcium nitrate solution is slowly poured using a peristaltic pump into a boiling solution containing diammonium hydrogenophosphate; $28 \% \mathrm{NH}_{4} \mathrm{OH}$ solution was added to the mixture and the $\mathrm{pH}$ was adjusted to 9 . The precipitate was aged with stirring at $80^{\circ} \mathrm{C}$ for $1 \mathrm{~h}$, then filtered, washed, dried at $70^{\circ} \mathrm{C}$ for $12 \mathrm{~h}$ and calcined at $500^{\circ} \mathrm{C}$. Each undesirable synthesized powder is instantly eliminated.

High purity $\alpha$-alumina $\left(\alpha-\mathrm{Al}_{2} \mathrm{O}_{3}\right)$ powder (Riedel-de haën, 98\%) was used in all experiments. The Fap has been used with $26.5 \mathrm{wt} \%$ amount because the human bone contains $1 \mathrm{wt} \%$ of fluoride approximately [32].

The $\mathrm{Al}_{2} \mathrm{O}_{3}$ and Fap powder were mixed in an agate mortar. The powder mixtures were milled in ethanol. After milling and homogenization, the mixtures were dried at $80^{\circ} \mathrm{C}$ for $24 \mathrm{~h}$. After drying, the powder mixtures were moulded in a cylinder having a diameter of $20 \mathrm{~mm}$ and a thickness of $6 \mathrm{~mm}$ and pressed under $150 \mathrm{MPa}$. The green compacts were sintered at various temperatures and holding times. The bulk density of the sintered body was calculated from the dimensions and weight. Three tests were made for every experiment. The relative error of apparent porosity value was about $1 \%$.

The particle size dimension of the powder was measured by means of Micrometrics Sedigraph 5000. The specific surface area (SSA) was measured by azotes absorption from the BET method (ASAP 2010) [33]. The main particle size $\left(\mathrm{D}_{\mathrm{BET}}\right)$ was calculated by assuming the primary particles to be spherical [30]:

$$
D_{B E T}=\frac{6}{S \rho}
$$

where $\rho$ is the theoretical density of $\mathrm{Al}_{2} \mathrm{O}_{3}\left(3.90 \mathrm{~g} / \mathrm{cm}^{3}\right)$ or Fap $\left(3.19 \mathrm{~g} / \mathrm{cm}^{3}\right)$, and $\mathrm{S}$ is the SSA of powder.

The samples before and after sintering were examined in an X-ray diffractometer using $\mathrm{CuK} \alpha$ (PHILIPS-PAN-

ALYTICAL; X'PERT pro MPD); the crystalline phases were identified by reference to the International Center for Diffraction Data (ICDD) cards. The samples were also submitted to infrared (IR) spectrometric analysis (Spectrum BX) using $\mathrm{KBr}$. The $\mathrm{Al}_{2} \mathrm{O}_{3}-26.5 \mathrm{wt} \%$ Fap composites were characterized by high resolution solid state using a Bruker 300WB spectrometer. NMR spectra were recorded at a ${ }^{31} \mathrm{P}$ frequency of $121.5 \mathrm{MHz}$ (field of $7.04 \mathrm{~T}$ ) and ${ }^{27} \mathrm{Al}$ frequency of 78.2 MHz (field of 7.04 T). The ${ }^{31} \mathrm{P}$ NMR chemical shifts reference is the phosphoric acid $\mathrm{H}_{3} \mathrm{PO}_{4}$. The ${ }^{27} \mathrm{Al}$ NMR chemical shifts were referenced to a static signal obtained from an aqueous aluminium chloride solution $\mathrm{AlCl}_{3} \cdot 6 \mathrm{H}_{2} \mathrm{O}$. The obtained products were examined by scanning electron microscope (SEM) (PHILIPS XL 30).

Differential thermal analysis and thermogravimetry were carried out using about $30 \mathrm{mg}$ of powder (DTA-TG; Model Setaram). The heating and cooling rates were respectively $10^{\circ} \mathrm{C} \mathrm{min}^{-1}$ and $20^{\circ} \mathrm{C} \cdot \mathrm{min}^{-1}$. Linear shrinkage was determined by dilatometry (Setaram) using the same thermal cycle as the one used for DTA.

The mechanical resistance was determined by Brazilian test (Lloyd EZ50). The optimum rupture strength $\sigma_{r}$ was offered by equation [17]:

$$
\sigma_{r}=\frac{F}{S}=\frac{2 F}{\pi D e}
$$

where $F$ is the tensile strength and $\mathrm{D}$ and e are the diameter and the thickness of the samples.

\section{Results and Discussion}

\subsection{Characterization of the Ceramic Powders}

The SSA, the calculated average grain sizes $\mathrm{D}_{\mathrm{BET}}$ (Equation (1)) and the particles size distribution data (measured by granulometric repartition) for $\mathrm{Al}_{2} \mathrm{O}_{3}$ and Fap powder are showed in Table 1. The difference between the value deducted by SSA $\left(\mathrm{D}_{\mathrm{BET}}\right)$ and by granulometric repartition $\left(\mathrm{D}_{50}\right)$ was probably due to the presence of agglomerates in the initial powder.

The X-ray diffraction pattern of alumina shows only peaks of $\alpha$ phase (Figure 1(a)). The X-ray diffraction pattern of fluorapatite powder reveals peaks of Fap and $\mathrm{CaO}$ traces (Figure 1(b)). It must be kept in mind that XRD analysis does not detect the presence of a small amount of impurities, especially when compounds have poor crystallinity [34]. The presence of $\mathrm{CaO}$ is confirmed by the phenolphthalein test. A similar observation has already been made $[17,35]$. $\mathrm{CaO}$ is produced by solid reaction between $\mathrm{CaF}_{2}$ and $\mathrm{H}_{2} \mathrm{O}$, which can be expressed by the following equation [36]:

$$
\mathrm{CaF}_{2}+\mathrm{H}_{2} \mathrm{O} \rightarrow \mathrm{CaO}+2 \mathrm{HF}
$$

$\mathrm{CaF}_{2}$ was contained in the synthesised Fap powder as impurity.

IR spectra of the alumina and fluorapatite powders (Figure 2) illustrate only alumina and fluorapatite characteristic bands. From the IR spectrum of alumina (Figure 2(a)), the absorption bands at 422, 452, 500, 558, 594,

Table 1. SSA, average grain size obtained by different analysis of $\mathrm{Al}_{2} \mathrm{O}_{3}$ and $\mathrm{Fap}$ powders.

\begin{tabular}{ccccc}
\hline & $\begin{array}{c}\text { SSA } \\
\left(\mathrm{m}^{2} / \mathrm{g}\right)\end{array}$ & $\mathrm{D}_{\mathrm{BET}}(\mu \mathrm{m}) \pm 0.2$ & $\begin{array}{c}\mathrm{D}_{50}(\mu \mathrm{m}) \pm \\
0.2\end{array}$ & $\mathrm{~d}^{\mathrm{a}}$ \\
\hline Fap & 29.00 & 0.07 & 3.00 & 3.19 \\
$\alpha-\mathrm{Al}_{2} \mathrm{O}_{3}$ & 2.87 & 0.53 & 7.00 & 3.90 \\
Composites & 9.80 & 0.40 & 5.94 & 3.70 \\
\hline${ }^{a}$ Theoretical density & & &
\end{tabular}



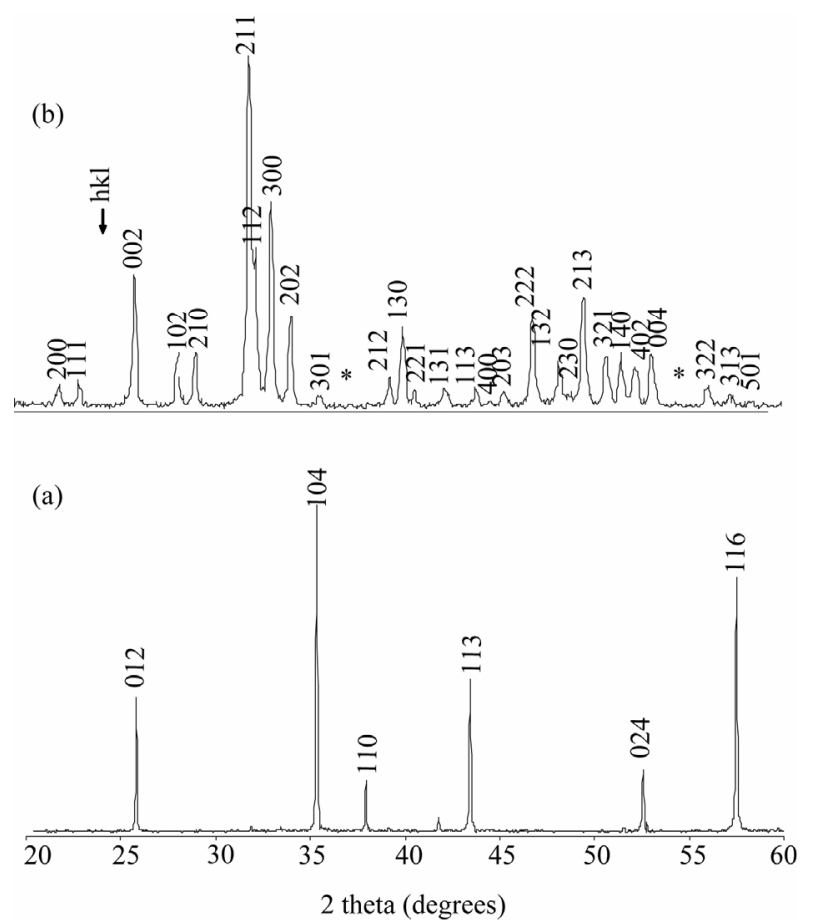

Figure 1. XRD patterns for: (a) $\mathrm{Al}_{2} \mathrm{O}_{3}$ powder; (b) Fap powder (*: $\mathrm{CaO})$.

656 and $770 \mathrm{~cm}^{-1}$ are allotted to the group Al-O [37-40]. From the Fap one (Figure 2(b)), the absorption bands which appear to $468,562,602$ and $900-1100 \mathrm{~cm}^{-1}$ are related to phosphate group, whereas those which appear at 1642 and $3448 \mathrm{~cm}^{-1}$ are assigned to the adsorbed water molecule. The absorption bands detected at 798 and 1392 $\mathrm{cm}^{-1}$ are allotted respectively to $\mathrm{HPO}_{4}^{2-}$ and $\mathrm{NO}_{3}^{-}$ groups, present in the form of impurities in the initial powder $[29,41,42]$.

However, it is not excluded that the powders contain other phases not detected by the IR radiations.

The ${ }^{31} \mathrm{P}$ MAS-NMR solid spectrum of the fluorapatite powder was presented in Figure 3(a). We observe only one peak which appears at $2.84 \mathrm{ppm}$ (only one environment of the core phosphorus), proving the absence of secondary products accompanying the fluorapatite synthesis. The ${ }^{27} \mathrm{Al}$ MAS-NMR solid spectrum of alumina powder was presented in Figure 3(b). We notice the presence of three peaks characteristic of aluminium; two first ones at $7 \mathrm{ppm}$ and $13 \mathrm{ppm}$ corresponding to octahedral Al sites and the other at $35 \mathrm{ppm}$ which corresponds to pentahedral Al.

\subsection{Thermal Characterization of the Ceramic Powders and the $\mathrm{Al}_{2} \mathrm{O}_{3}-26.5 \mathrm{wt} \%$ Fap Composites}

A thermal behaviour study of the initial powders and the composite has proved to be a powerful technique for un- (b)
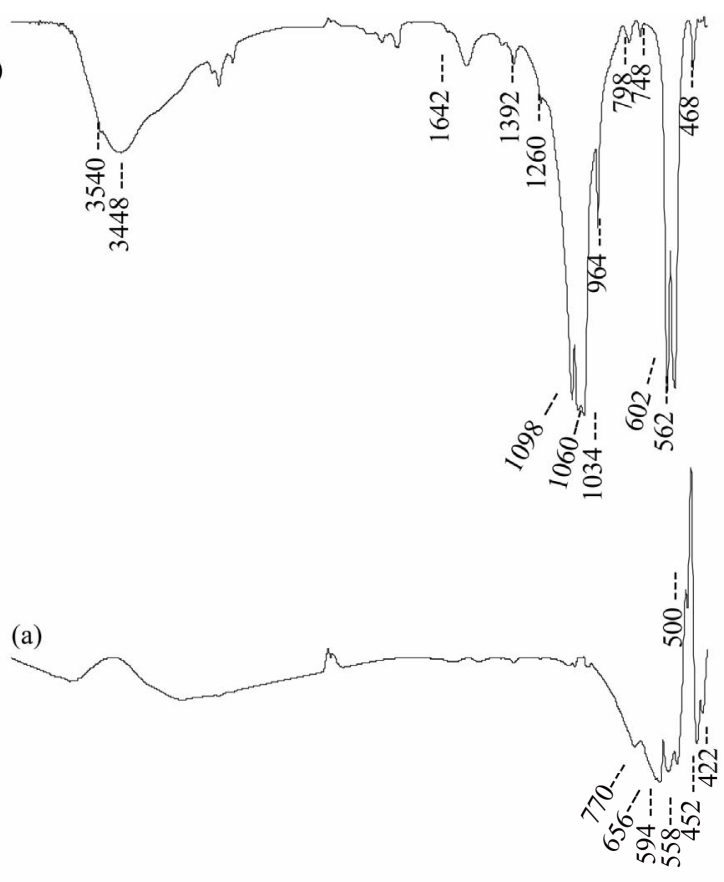

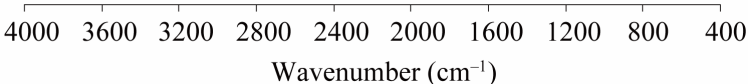

Figure 2. IR spectra of: (a) $\mathrm{Al}_{2} \mathrm{O}_{3}$ powder; (b) fluorapatite powder.

derstanding physical phenomena during the sintering. The dilatometric analysis and the differential thermal analysis were used. Dilatometric analysis was performed at $1500^{\circ} \mathrm{C}$. The analysis of the alumina powder shows a light expansion followed by an even weaker contraction (Figure 4(a)). The dilatometric measurements of alumina powder showed that shrinkage was not begun even at $1400^{\circ} \mathrm{C}$. For the Fap powder, the shrinkage began at $950^{\circ} \mathrm{C}$ and continued to $1200^{\circ} \mathrm{C}$ (Figure 4(b)). The optimum sintering temperature of this powder is around $1030^{\circ} \mathrm{C}$. Above $1200^{\circ} \mathrm{C}$, a slight expansion takes place, which is probably due to the formation of a liquid phase. The addition of $26.5 \mathrm{wt} \%$ Fap in the matrix of alumina reduces the shrinkage beginning temperature of about $400^{\circ} \mathrm{C}$ in comparison with pure alumina (Figure 4(c)). Therefore, the presence of alumina delays the sintering of the Fap. Moreover, we notice the presence of samples retractions of about $10 \%$, indicating the composite densification.

The alumina powder, presents an endothermic peak in the DTA curve (Figure 5(a)), the peak around $1051^{\circ} \mathrm{C}$ probably marks the elimination of impurities potentially present in the commercial powder (commercial $\mathrm{Al}_{2} \mathrm{O}_{3}$ powder contain approximately $2 \mathrm{wt} \%$ of impurity not detected by XRD analysis). Typical DTA curve of Fap powder illustrates two endothermic peaks (Figure 5(b)). 

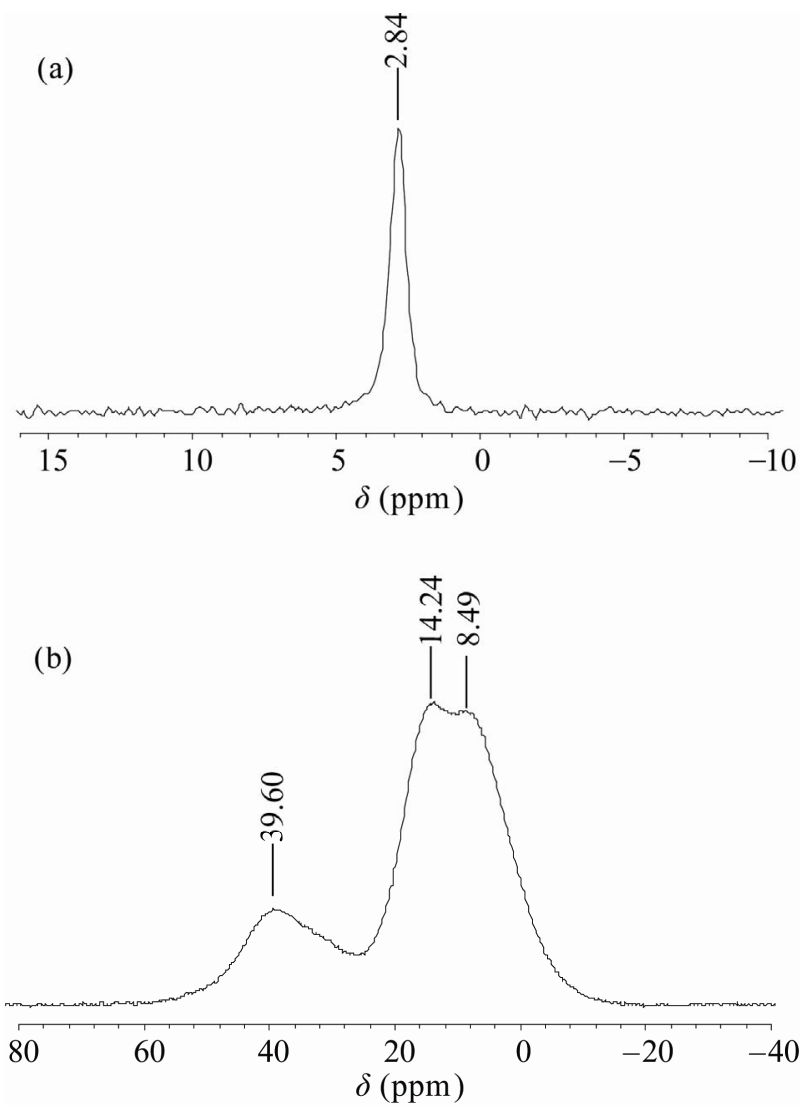

Figure 3. ${ }^{31} \mathrm{P}$ NMR spectrum of fluorapatite powder and ${ }^{27}$ Al NMR spectrum of $\alpha$-alumina powder.

The first is located at $180^{\circ} \mathrm{C}$, corresponding to the poder dehydration. The second appearing at $1192^{\circ} \mathrm{C}$, probably attributed to the formation of a liquid phase, which is formed from binary eutectic between $\mathrm{CaF}_{2}$ and Fap $[28,29]$. For the composite powder DTA, the curve presents the same transitions, but the second arises at higher temperature $\left(1064^{\circ} \mathrm{C}\right)$ probably due to the presence of the Fap (Figure 5(c)). In addition, we remark the absence of the peak around $1192^{\circ} \mathrm{C}$ attributed to the liquid phase formation in Fap powder. This absence is probably due to the inhibiting effect of alumina on the mixture.

After thermal analysis, we can notice that alumina was not yet sintered at $1500^{\circ} \mathrm{C}$. The addition of Fap powder lets the mixture sinter from a temperature about $1010^{\circ} \mathrm{C}$. So, an optimisation of sintering conditions is required to elaborate alumina-Fap composites.

\subsection{Sintering and Characterization of the $\mathrm{Al}_{2} \mathrm{O}_{3}$ -26.5 wt\% Fap Composites}

\subsubsection{Sintering of the Composites}

Figure 6(a) shows the mechanical properties of the $\mathrm{Al}_{2} \mathrm{O}_{3}-26.5 \mathrm{wt} \%$ Fap composites samples according to the sintering temperature. The rupture strength of sintered

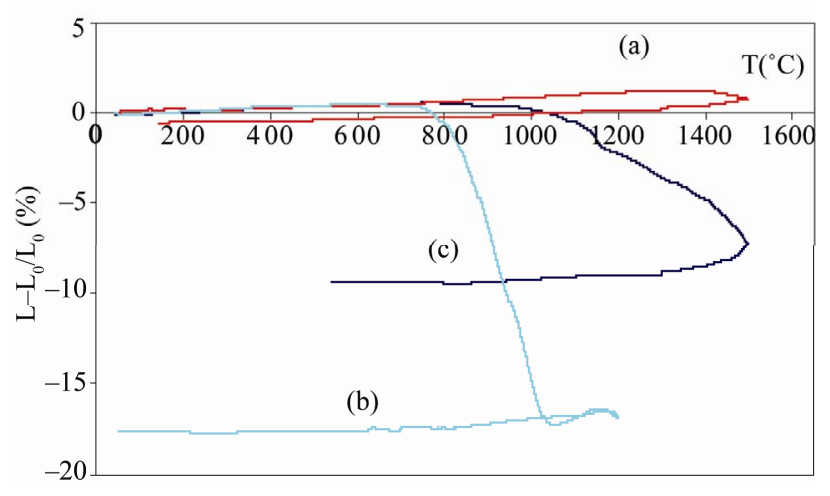

Figure 4. Linear shrinkage versus temperature of: (a) $\mathrm{Al}_{2} \mathrm{O}_{3}$; (b) Fap; (c) $\mathrm{Al}_{2} \mathrm{O}_{3}$-Fap composite powders.

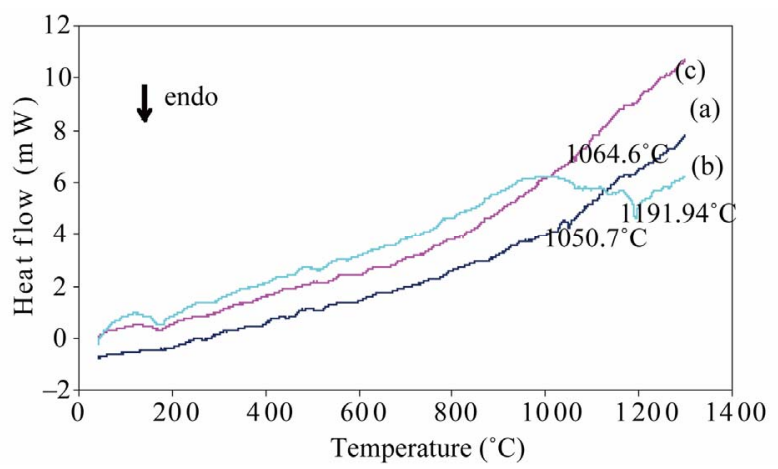

Figure 5. DTA curves of: (a) $\mathrm{Al}_{2} \mathrm{O}_{3}$; (b) Fap; (c) $\mathrm{Fap}-\mathrm{Al}_{2} \mathrm{O}_{3}$ composite.

composites was slightly improved up to $1300^{\circ} \mathrm{C}$. Above this temperature, it suddenly increases to reach its maximum value at $1600^{\circ} \mathrm{C}(21.7 \mathrm{MPa})$. This can be attributed to the improvement in the density of sintered composites. So, the relative density passes from $60 \%$ at $1300^{\circ} \mathrm{C}$ to $85 \%$ at $1600^{\circ} \mathrm{C}$.

The results of the mechanical properties according to the sintering temperature are confirmed by the porosity measurements. Indeed, the apparent porosity remains constant until a temperature of about $1300^{\circ} \mathrm{C}$ and than decreases with the increase of sintering temperature (Figure 6(b)). The minimum of apparent porosity reaches $14 \%$ at $1600^{\circ} \mathrm{C}$.

In order to lower the sintering temperature while guarding the mechanical properties, other experiments were carried out on some samples fired at $1500^{\circ} \mathrm{C}$ at various holding times (from 30 minutes to 7 hours). Figure 7 (a) shows the mechanical properties evolution of $\mathrm{Al}_{2} \mathrm{O}_{3}-26.5 \mathrm{wt} \%$ Fap composites versus the holding time. For 5 hours, the rupture strength reaches its maximum value of 26.4 MPa. For longer holding times, the rupture strength decreases abruptly. Those evolutions of mechanical properties can be explained by apparent porosity results (Figure 7(b)). This curve illustrates a minimum 


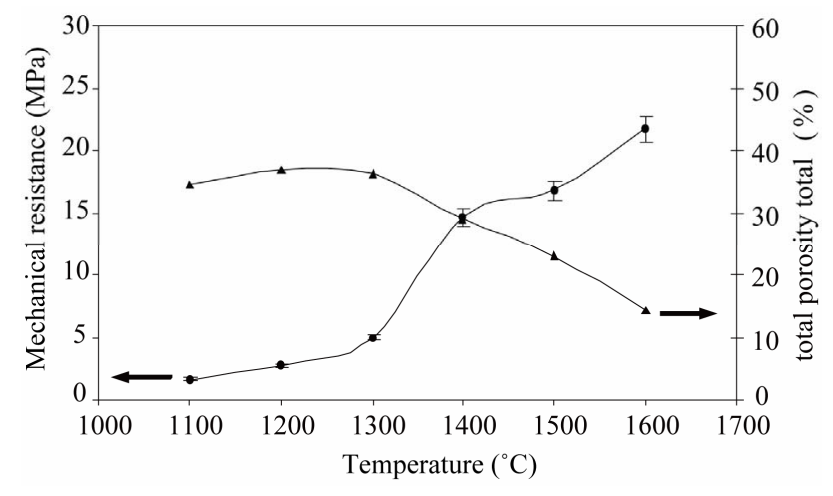

Figure 6. Mechanical resistance and total porosity versus temperature of $\mathrm{Al}_{2} \mathrm{O}_{3}$-Fap composites sintered for $1 \mathrm{~h}$.

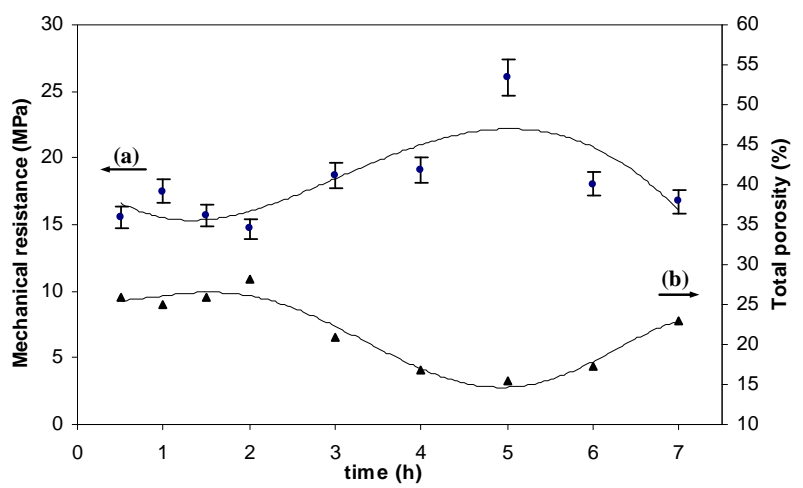

Figure 7. Mechanical resistance and total porosity versus holding time of $\mathrm{Al}_{2} \mathrm{O}_{3}$-Fap composites sintered at $1500^{\circ} \mathrm{C}$.

apparent porosity at about $15 \%$ corresponding to the highest rupture strength.

The whole results obtained show that it is possible to obtain a Fap- $\mathrm{Al}_{2} \mathrm{O}_{3}$ composite well densified. The adopted sintering temperatures and durations are closer to the sintering conditions of the alumina than the fluorapatite ones. Indeed, Fap presents a good aptitude for sintering in the temperature range $900^{\circ} \mathrm{C}-1100^{\circ} \mathrm{C}$ during one hour $[17,29,30,43]$. Whereas the alumina sintering is carried out in the temperatures range between 1400 and $1750^{\circ} \mathrm{C}$ [44-51]. The thermal study carried out on the $\mathrm{Al}_{2} \mathrm{O}_{3}-26.5$ wt $\%$ Fap composite proved that mixing $\mathrm{Al}_{2} \mathrm{O}_{3}$ and Fap decreases the temperature of the sintering beginning compared to pure alumina. Indeed, it decreases from a temperature above $1400^{\circ} \mathrm{C}$ to $1030^{\circ} \mathrm{C}$. Moreover, we notice that the alumina inhibits the Fap decomposition and the liquid phase formation revealed in the sintering of pure Fap. Further, the mechanical resistance of Fap$\mathrm{Al}_{2} \mathrm{O}_{3}$ composites showed a higher value than that of pure Fap. F. Ben Ayed et al and N. Bouslama et al reported that the mechanical resistance of Fap and TCPFap ceramics was about $14 \mathrm{MPa}$ and $9.4 \mathrm{MPa}$, respectively [52,53].

Sintering was driven by many parameters and phe- nomena. In fact, when powders have different grain size and chemical nature, much driving force and phenomena will appear. The difference of fusion temperatures and densification start of different departure powders conduce to the fluctuation of the sintering process results. All those phenomena will modify the mechanical resistance and the densities of specimens [43].

\subsubsection{Characterization of SinteredSamples}

After sintering process, the samples have been subjected to various characterization techniques such as the $\mathrm{x}$-ray diffraction (XRD), infrared spectroscopy (IR), ${ }^{31} \mathrm{P}$ and ${ }^{27} \mathrm{Al}$ magic angle spinning nuclear magnetic resonance (MAS-NMR) and scanning electronic microscopy (SEM).

The X-ray diffraction patterns of $\mathrm{Al}_{2} \mathrm{O}_{3}$-Fap composites sintered at various temperatures (from $1300^{\circ} \mathrm{C}$ to $1600^{\circ} \mathrm{C}$ ) during one hour were shown in Figure 8. The XRD pattern of samples sintered at $1300^{\circ} \mathrm{C}$ shows the presence of $\mathrm{Al}_{2} \mathrm{O}_{3}$ and Fap (Figure 8a). All the diffraction peaks correspond to the mixture of alumina and Fap. Those spectra are identical to those of initial mixed powders. The XRD patterns of samples sintered at $1400^{\circ} \mathrm{C}$,

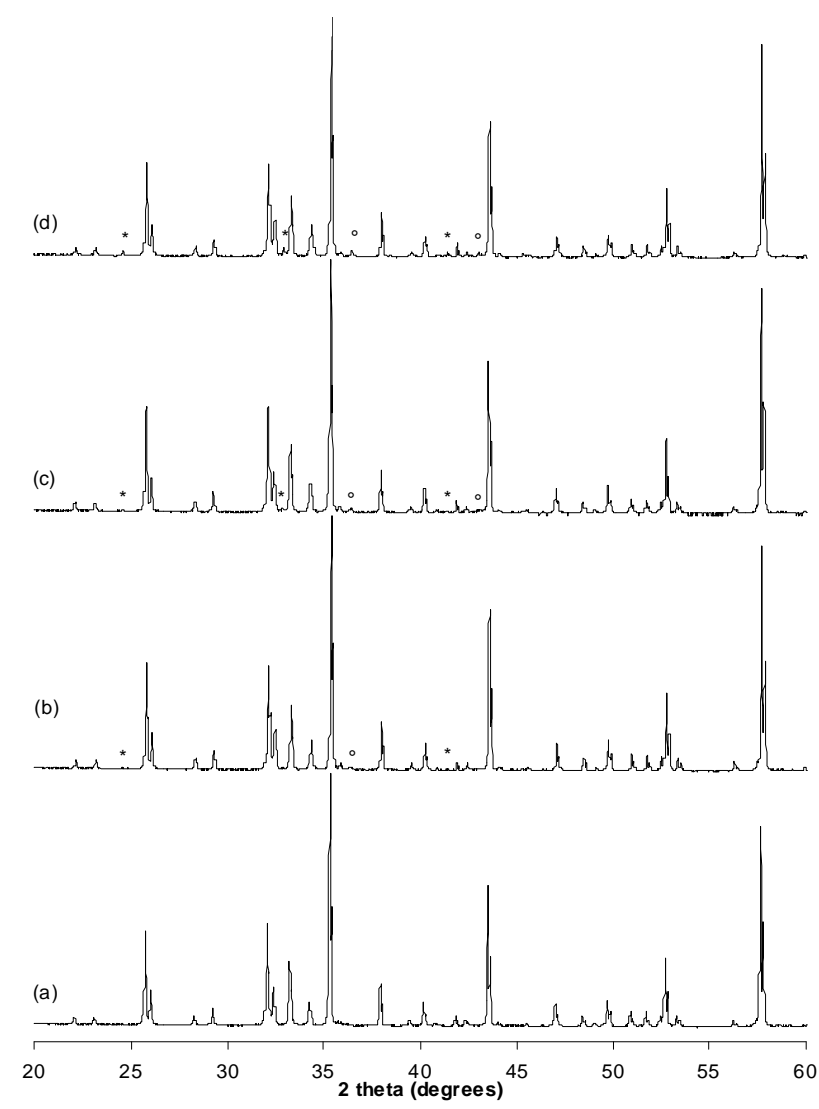

Figure 8. XRD spectrums of $\mathrm{Al}_{2} \mathrm{O}_{3}$-Fap composites sintered at various temperatures for $1 \mathrm{~h}$ : (a) $1300^{\circ} \mathrm{C}$; (b) $1400^{\circ} \mathrm{C}$; (c) $1500^{\circ} \mathrm{C}$; (d) $1600^{\circ} \mathrm{C}\left(*\right.$ : $\left.\mathrm{Ca}_{2} \mathrm{Al}_{2} \mathrm{O}_{5} ; \mathrm{CaAl}_{12} \mathrm{O}_{19}\right)$. 
$1500^{\circ} \mathrm{C}$ and $1600^{\circ} \mathrm{C}$ show in more the presence of two new phases which are probably attributed to $\mathrm{Ca}_{2} \mathrm{Al}_{2} \mathrm{O}_{5}$ and $\mathrm{CaAl}_{12} \mathrm{O}_{19}$ (Figures 8(b)-(d)).

In earlier studies, many calcium aluminates phases were produced at high temperature by decomposition of Hap or Fap into $\mathrm{CaO}$ and $\mathrm{Ca}_{3}\left(\mathrm{PO}_{4}\right)_{2}$ and then reacted with alumina to form calcium aluminates [54-56]. This decomposition is demonstrated by a relative decrease of Fap peaks intensity [54]. For our composite, the Fap peaks intensity is steady during the sintering process even at high temperature. So, we can conclude that our Fap was not decomposed and the calcium aluminates formation is probably produced by solid reactions between $\mathrm{CaO}$ (as impurity) and $\mathrm{Al}_{2} \mathrm{O}_{3}$, which is explained as follows [57]:

$$
\begin{aligned}
& \mathrm{CaO}+6 \mathrm{Al}_{2} \mathrm{O}_{3} \rightarrow \mathrm{CaAl}_{12} \mathrm{O}_{19} \\
& 2 \mathrm{CaO}+\mathrm{Al}_{2} \mathrm{O}_{3} \rightarrow \mathrm{Ca}_{2} \mathrm{Al}_{2} \mathrm{O}_{5}
\end{aligned}
$$

The peaks relative to the new calcium aluminates formed have a low intensity relative to their low amount. In addition, sintering time has not any influence on the composition of the samples. This interpretation is illustrated in Figure 9.

Figure 10 and Figure 11 illustrate the FT-IR spectroscopic analysis; it is performed for composite samples sintered at various temperatures and for various sintering times. A comparison of spectra for various sintering temperatures allows an understanding of the composite structural evolution. Below $1400^{\circ} \mathrm{C}$, the vibrational spectrum is not modified. This indicates that the local structure is not modified. Indeed, most bands were characteristic of phosphate (940-1076 cm alumina $\left(418-752 \mathrm{~cm}^{-1}\right)$. For higher temperature, a novel band arises at $948 \mathrm{~cm}^{-1}$ and becomes well-defined at $1600^{\circ} \mathrm{C}$ [58]. This band is probably attributed to either the Al-O stretching or bending regions of aluminium in tetrahedral sites. This clearly indicates the formation of the calcium aluminates, as demonstrated by $\mathrm{X}$-ray analysis.

The ${ }^{31} \mathrm{P}$ MAS-NMR spectra of $\mathrm{Al}_{2} \mathrm{O}_{3}-26.5 \mathrm{wt} \%$ Fap composites sintered for $1 \mathrm{~h}$ at various temperatures $\left(1300^{\circ} \mathrm{C}, 1400^{\circ} \mathrm{C}, 1500^{\circ} \mathrm{C}\right.$ and $\left.1600^{\circ} \mathrm{C}\right)$ and others sintered at $1500^{\circ} \mathrm{C}$ for various holding times $(1 \mathrm{~h}, 2 \mathrm{~h}, 3 \mathrm{~h}, 4 \mathrm{~h}$, $5 \mathrm{~h}$ and $6 \mathrm{~h}$ ) were presented in Figure 12(i) and Figure 12(ii) respectively. The spectra show an intense peak at $2.86 \mathrm{ppm}$ and $2.88 \mathrm{ppm}$ respectively related to the phosphorus of Fap. These results prove that the local environment of the phosphorus atoms hasn't changed during the sintering process. Thus, Fap structure was conserved.

Figure 13 show the ${ }^{27} \mathrm{Al}$ MAS-NMR spectra collected for $\mathrm{Al}_{2} \mathrm{O}_{3}-26.5 \mathrm{wt} \%$ Fap green composites and others sintered for $1 \mathrm{~h}$ at various temperatures $\left(1300^{\circ} \mathrm{C}, 1400^{\circ} \mathrm{C}\right.$, $1500^{\circ} \mathrm{C}$ and $1600^{\circ} \mathrm{C}$ ). For unsintered $\mathrm{Al}_{2} \mathrm{O}_{3}$-Fap composites (Figure 13(a)), the aluminium is primarily in pentahedral and in octahedral sites. For sintered ones (Figure 13

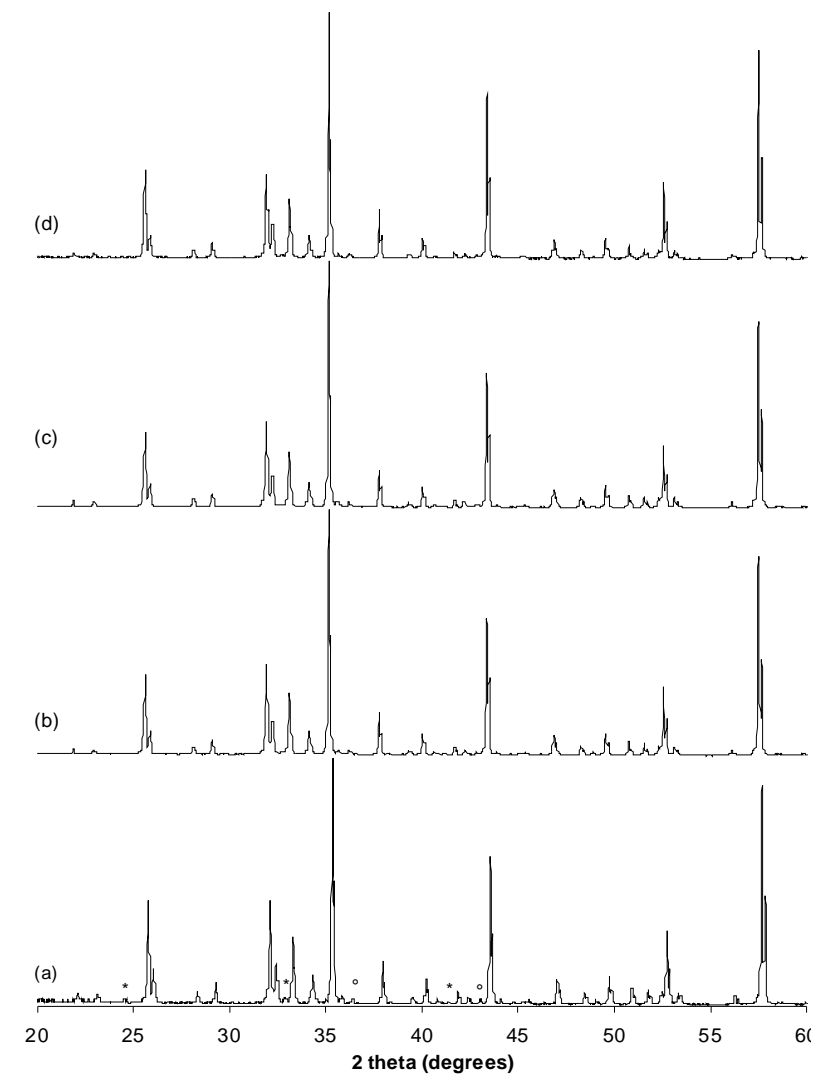

Figure 9. XRD spectrums of $\mathrm{Al}_{2} \mathrm{O}_{3}$-Fap composites sintered at $1500^{\circ} \mathrm{C}$ for: (a) $1 \mathrm{~h}$; (b) $3 \mathrm{~h}$; (c) $5 \mathrm{~h}$; (d) $6 \mathrm{~h} \mathrm{(*:} \mathrm{Ca}_{2} \mathrm{Al}_{2} \mathrm{O}_{5}$; $\left.\mathrm{CaAl}_{12} \mathrm{O}_{19}\right)$.

(b)-(e)) the spectra consist of signals of three aluminium environment: that for $\mathrm{AlO}_{4}$ at about $70 \mathrm{ppm}$, that for $\mathrm{AlO}_{5}$ at about $30 \mathrm{ppm}$ and $40 \mathrm{ppm}$ and that for $\mathrm{AlO}_{6}$ at about $8 \mathrm{ppm}$ and $16 \mathrm{ppm}$. The intensity of tetrahedral signal is very low compared with that of both pentahedral and octahedral signals. The estimated concentrations of $\mathrm{AlO}_{4}, \mathrm{AlO}_{5}$ and $\mathrm{AlO}_{6}$ are reported in Table 2. In heated samples, when the sintering temperature increases, the fraction of both the tetrahedral and pentahedral sites increases at the expense of octahedral sites. In other words, the aluminium in octahedral symmetry is forced into tetrahedral and pentahedral sites. According to these results, sintering of $\mathrm{Al}_{2} \mathrm{O}_{3}$-Fap composites provoke the structural rearrangement of the aluminium coordination. A similar result was proved by G. Del Angel et al [59]. Indeed, they show that, in presence of lanthanum, the aluminium in octahedral symmetry is forced into tetrahedral sites.

The structural rearrangement of the aluminium coordination is also probably produced by the calcium aluminates formation which is detected by the XRD analysis. In fact, these two products contain aluminium in tetrahedral sites $[60,61]$.

The SEM examination of the fracture surface of the 


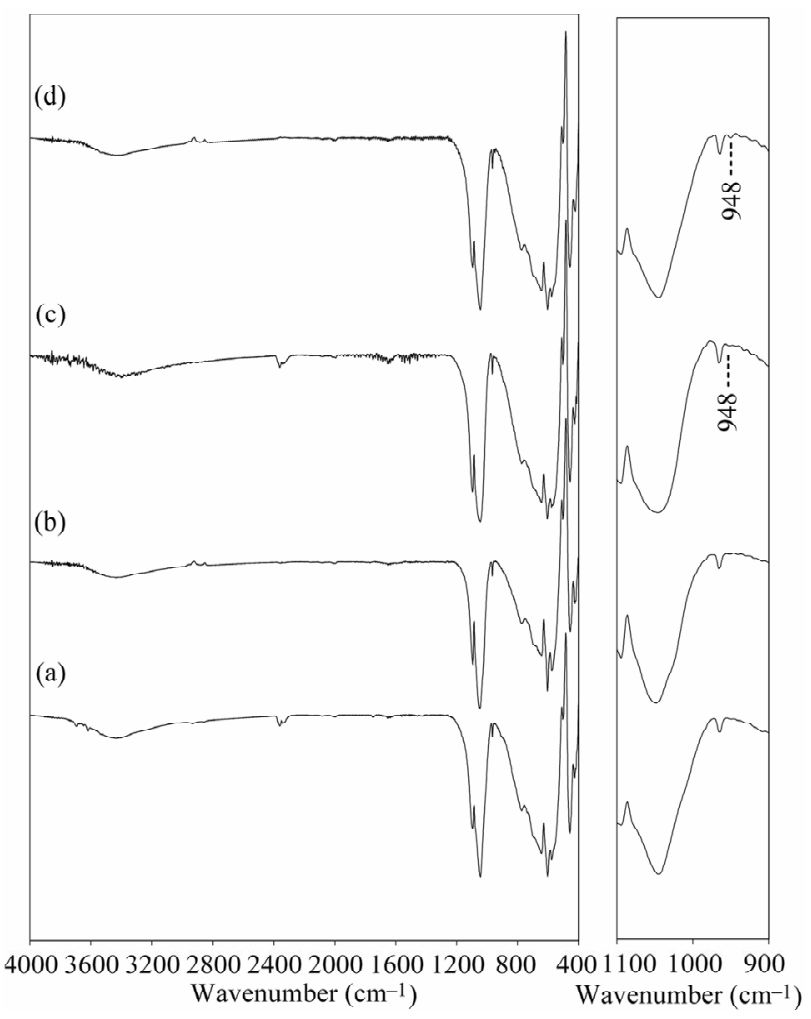

Figure 10. FTIR spectra of $\mathrm{Al}_{2} \mathrm{O}_{3}$-Fap composites sintered at various temperatures for $1 \mathrm{~h}$ : (a) $1300^{\circ} \mathrm{C}$; (b) $1400^{\circ} \mathrm{C}$; (c) $1500^{\circ} \mathrm{C}$; (d) $1600^{\circ} \mathrm{C}$.

$\mathrm{Al}_{2} \mathrm{O}_{3}$-Fap composites sintered at various temperatures $\left(1300^{\circ} \mathrm{C}, 1400^{\circ} \mathrm{C}, 1500^{\circ} \mathrm{C}\right.$ and $1600^{\circ} \mathrm{C}$ ) for one hour was reported in Figure 14. The fracture surface reveals a distinct difference in the samples microstructure. At $1300^{\circ} \mathrm{C}$, the sample presents an important intergranular porosity which disappears partially when temperature increases (Figures 14(a)-(d)). In addition, we notice the presence of two grain size ranges: grains which have an average size $3 \mu \mathrm{m}$ relative to alumina phases and the others which have an average size about $10 \mu \mathrm{m}$ relative to Fap phases. Above $1600^{\circ} \mathrm{C}$, the microstructure was completely transformed. So, grains went through the stage of partial coalescence, and then a continuous phase was developed with the sintering temperature increase and especially at $1600^{\circ} \mathrm{C}$. A dense bioceramic was clearly formed: dense contacts between the grains and well-formed grain boundary zone.

The micrograph investigation realised for various holding times shows that samples fired during 1 hour until 5 hours present an improvement of structure by a partial disappearance of porosity which reaches its maximum during 5 hours (Figure 15(b)). For a holding time about 6 hours, micrograph shows a reappearance of inter and intragranular porosity which is caused by an exaggerated grain growth and probably by impurities

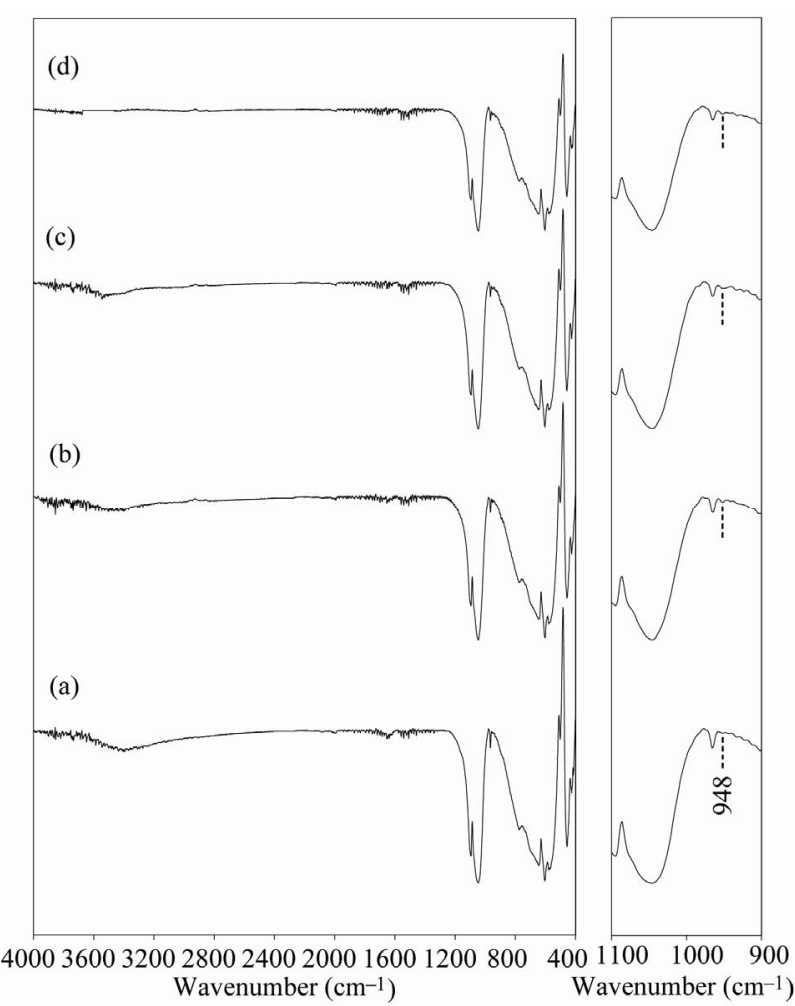

Figure 11. FTIR spectra of $\mathrm{Al}_{2} \mathrm{O}_{3}$-Fap composites sintered at $1500^{\circ} \mathrm{C}$ for: (a) $1 \mathrm{~h}$; (b) $3 \mathrm{~h}$; (c) $5 \mathrm{~h}$; (d) $6 \mathrm{~h}$.

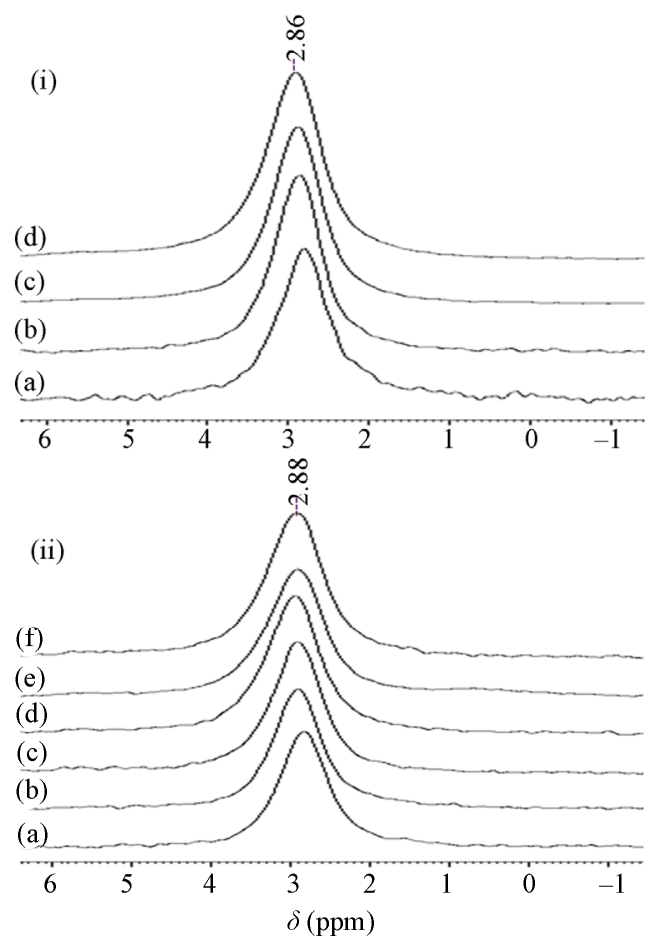

Figure 12. ${ }^{31} \mathrm{P}$ NMR spectra of $\mathrm{Al}_{2} \mathrm{O}_{3}$-Fap composites (i) sintered at different temperatures for $1 \mathrm{~h}$; (ii) sintered at $1500^{\circ} \mathrm{C}$ for different holding times. 


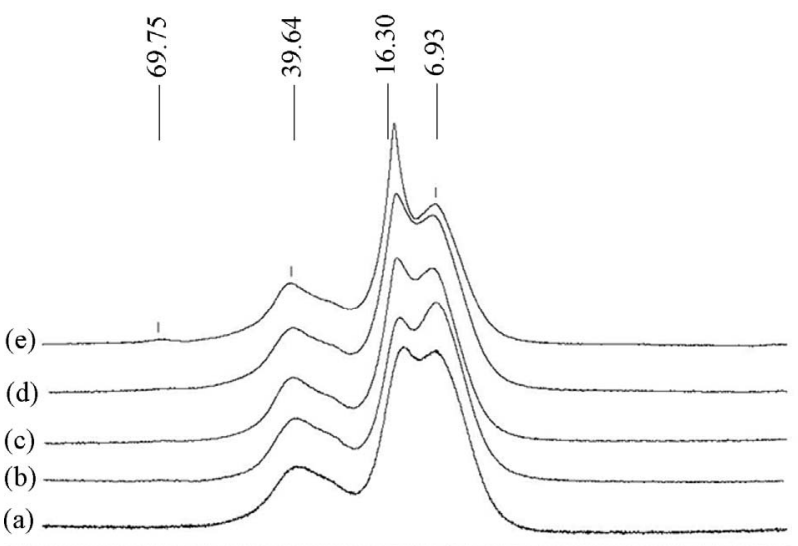

$10090 \quad 8070 \quad 60 \quad 50 \quad 40 \quad 30 \quad 20 \quad 10 \quad 0-10-20-30-40-50-60 \mathrm{ppm}$

Figure 13. ${ }^{27} \mathrm{Al}$ NMR spectra of (a) unfired $\mathrm{Al}_{2} \mathrm{O}_{3}$-Fap composites; (b) sintered at $1300^{\circ} \mathrm{C}$; (c) at $1400^{\circ} \mathrm{C}$; (d) at $1500^{\circ} \mathrm{C}$; (e) at $1600^{\circ} \mathrm{C}$.

volatilisation. These observations are a confirmation of mechanical properties and porosity.

It has been shown in the present work that a fluoride dental implant was elaborated and then characterized. Optimum conditions of sintering were obtained. Unfor tunately, the rupture strength of our bioceramic does not exceed a value of about $26.4 \mathrm{MPa}$ as compared to 500
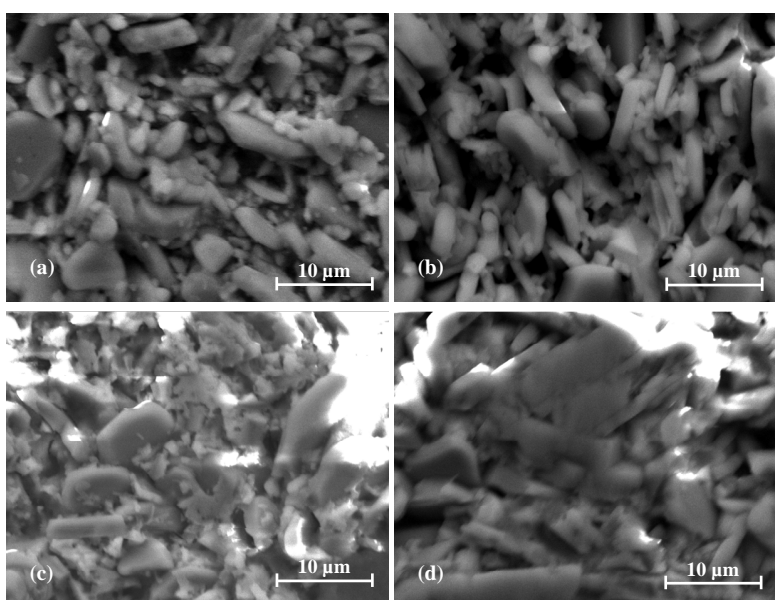

Figure 14. SEM micrographs of Al2O3-Fap composites sintered at various temperatures for $1 \mathrm{~h}$ : (a) $1300^{\circ} \mathrm{C}$; (b) $1400^{\circ} \mathrm{C}$; (c) $1500^{\circ} \mathrm{C}$; (d) $1600^{\circ} \mathrm{C}$.

Table 2. Observed proportions of $\mathrm{AlO}_{4}, \mathrm{AlO}_{5}, \mathrm{AlO}_{6}$ in $\mathrm{Al}_{2} \mathrm{O}_{3}$ -26.5 wt \% Fap composites sintered at different temperature for $1 \mathrm{~h}$.

\begin{tabular}{cccc}
\hline $\mathrm{T}^{\circ}\left({ }^{\circ} \mathrm{C}\right)$ & $\mathrm{AlO}_{4}$ & $\mathrm{AlO}_{5}$ & $\mathrm{AlO}_{6}$ \\
\hline 1300 & 0.09 & 21.49 & 78.42 \\
1400 & 0.11 & 21.79 & 78.09 \\
1500 & 0.13 & 22.94 & 76.95 \\
1600 & 0.30 & 24.42 & 75.29 \\
\hline
\end{tabular}
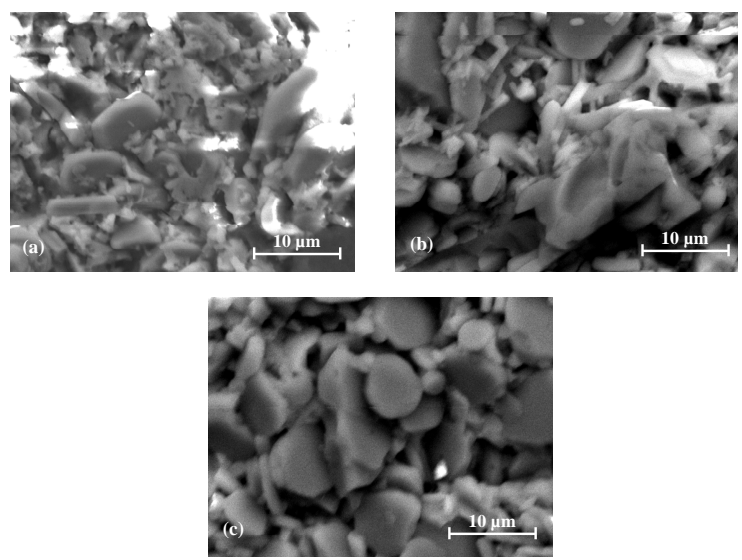

Figure 15. SEM micrographs of $\mathrm{Al}_{2} \mathrm{O}_{3}$-Fap composites sintered at $1500^{\circ} \mathrm{C}$ for: (a) $1 \mathrm{~h}$; (b) $5 \mathrm{~h}$; (c) $6 \mathrm{~h}$.

MPa for dental enamel. However, with comparison to the other bioceramics, such as Hydroxyapatite, fluorapatite or tricalcium phosphate $[16,17,54]$, our bioceramic presents higher mechanical properties with an important porosity. And compared to alumina, properties are lower, but the elaboration was performed at lower temperature. As a prospect, microstructure improvement of our composite can be realised by the addition of sintering agents, like $\mathrm{CaO}, \mathrm{TiO}_{2}$, which react at the alumina-Fap interface, so they increase the bending forces, or by the utilisation of physical inert reinforcement such as glass or carbon nanofibers.

\section{Conclusions}

In order to imitate its higher stability and better densification and mechanical properties, alumina was used. But its manufacturing reclaims a very high sintering temperature. Fap also presents a good sinterability, an excellent biocompatibility and direct bond formation with adjacent hard tissue. A marriage of both materials was developed, and a new material was successfully elaborated for the dental replacement. Physical and mechanical properties were studied, as well as structural characteristics. The following results were obtained.

(1) Dilatometric curve of alumina indicates that the powder was not sintered, even if we reach a temperature about $1500^{\circ} \mathrm{C}$. However, for Fap and composite the specimens were sintered. So Fap addition decreases the sintering temperature of alumina.

(2) A better densification of the composite was reached for a sintering temperature of about $1600^{\circ} \mathrm{C}$ for 1 hour holding time and with rupture strength near to $22 \mathrm{MPa}$.

(3) An improvement of the rupture strength above 26 $\mathrm{MPa}$, with guarding the same density, was obtained by decreasing the temperature of $100^{\circ} \mathrm{C}$ (became $1500^{\circ} \mathrm{C}$ ), but for a holding time about 5 hours. 
(4) The presence of $\mathrm{CaO}$, in synthesized Fap, improves the mechanical resistance by formation of the calcium aluminates.

From the last notification, an improvement of densification and mechanical properties of our composite can be reached by adding an adequate proportion of $\mathrm{CaO}$ as a sintering agent or reinforcing the structure with inert fibers. This work is currently underway.

\section{References}

[1] L. L. Hench, "Bioceramics," Journal of the American Ceramic Society, Vol. 81, No.7, 1998, pp. 1705-1728.

[2] A. Clifford and R. Hill, "Apatite-Mullite Glass-Ceramics," Journal of Non-Crystalline Solids, Vol. 19, No. 6, 1996, pp. 346-351. doi:10.1016/0022-3093(95)00611-7

[3] L. L. Hench, "Bioceramics," Journal of the American Cramic Society, Vol. 81, No. 7, 1998, pp. 1705-1728.

[4] S. M. Best, A. E. Porter, E. S. Thian and J. Huang, "Bioceramics: Past, Present and for the Future," Journal of European Ceramic Society, Vol. 28, 2008, pp. 1319-1327. doi:10.1016/j.jeurceramsoc.2007.12.001

[5] L. M. Rodriguez-Lorenzo, J. N. Hart and K. A. Gross, "Influence of Fluorine in the Synthesis of Apatites. Synthesis of Solid Solutions of Hydroxyl-Fluorapatite," Biomaterials, Vol.24, 2003, pp. 3777-3785. doi:10.1016/S0142-9612(03)00259-X

[6] S. M. Barinova, L. I. Shvorneva, D. Ferro, I. V. Fadeeva and S. V. Tumano, "Solid Solution Formation at the Sintering of Hydroxyapatite-Fluorapatite Ceramics," Science and Technology of Advanced Materials, Vol. 5, 2004, pp. 537-541. doi:10.1016/j.stam.2004.02.012

[7] M. J. Larsen and A. Thorson, "A Comparaison of Some Effects of Fluoride on Apatite Formation in Vitro and in Vivo," Calcified Tissue International, Vol. 36, No. 6, 1984, pp. 690-696. doi:10.1007/BF02405391

[8] L. Gineste, M. Gineste, X. Ranz, A. Ellefterion, A. Guilhem, N. Rouquet and P. Frayssinet, "Degradation of Hydroxylapatite, Fluorapatite and Fluorhydroxyapatite Coatings of Dental Implants in Dogs," Journal of Biomedical Materials Research, Vol. 48, No. 3, 1999, pp. 224-234.

doi:10.1002/(SICI)1097-4636(1999)48:3<224::AID-JBM 5>3.0.CO;2-A

[9] B. H. Yoon, H. W. Kim, S. H. Lee, C. J. Bae, Y. H. Koh,Y. M. Kong and H. E. Kim, "Stability and Cellular Responses to Fluorapatite-Collagen Composites," Biomaterials, Vol. 26, 2005, pp. 2957-2963. doi:10.1016/j.biomaterials.2004.07.062

[10] K. A. Gross and K. A. Bhadang, "Sintered Hydroxyfluorapatite. Part III: Sintering and Resultant Mechanical Properties of Sintered Blends of Hydroxyapatite and Fluorapatite," Biomaterials, Vol. 25, 2004, pp. 1395-1405. doi:10.1016/j.biomaterials.2003.08.051

[11] S. V. Dorozhkin, "Bioceramics of Calcium Orthophosphates," Biomaterials, Vol. 31, 2010, pp. 1465-1485. doi:10.1016/j.biomaterials.2009.11.050
[12] M. Fulmer and P. W. Brown, "Low-Temperature Formation of Fluorapatite in Aqueous Solution," Journal of the American Ceramic Society, Vol.75, No.12 1992, pp. 401-407.

[13] P. Uwe, E. Angela and R. Christian, "A Pyrolytic Route for the Formation of Hydroxyapatite-Fluorapatite Solid Solutions," Journal of Materials Science, Material Medical, Vol. 4, No. 3, 1993, pp. 292-295.

[14] J. C. Elliott, "Structure and Chemistry of the Apatite and Other Calcium Orthophosphates," Elsevier Science., Amsterdam, 1994.

[15] E. D. Franz and R. Telle, "Reaction Hot Pressing of Fluorapatite for Dental Implants," In: P. Vincenzini, Ed., Hight Tech Ceramics, Elsevier Science, Amsterdam, 1987, pp. 31-41.

[16] E. Landi, A. Tampieri, G. Celotti and S. Sprio, "Densification Behaviour and Mechanisms of Synthetic Hydroxyapatites," Journal of European Ceramic Society, Vol. 20, 2000, pp. 2377-2387. doi:10.1016/S0955-2219(00)00154-0

[17] F. Ben Ayed, J. Bouaziz and K. Bouzouita, "Résistance Mécanique de la Fluorapatite, "Annales de Chimie-Science des Materiaux, Vol. 31, No. 4, 2006, pp. 393-406. doi:10.3166/acsm.31.393-406

[18] S. Agathopoulos, D. U. Tulyaganov, P. A. A. P. Marques, M. C. Ferro, M. H. V. Fernandes and R. N. Correia, "The Fluorapatite-Anorthite System in Biomedicine," Biomaterials, Vol. 24, 2003, pp. 1317-1331. doi:10.1016/S0142-9612(02)00468-4

[19] K. A. Gross and L. M. Rodriguez-Lorenzo, "Biodegradable Composite Scaffolds with an Interconnected Spherical Network for Bone Tissue Engineering," Biomaterials, Vol. 25, 2004, pp. 4955-4962. doi:10.1016/j.biomaterials.2004.01.046

[20] A. Rapacz-Kmita, A. Slosarczyk and Z. Paszkiewicz, "Mechanical Properties of Hap- $\mathrm{ZrO}_{2}$ Composites," Journal of European Ceramic Society, Vol. 26, 2006, pp. 1481-1488. doi:10.1016/j.jeurceramsoc.2005.01.059

[21] W. Zhenjun, H. Liping and Z. Chen, "Composite Biocoating of Hydroxyapatite $/ \mathrm{Al}_{2} \mathrm{O}_{3}$ on Titanium Formed by Al Anodization and Electrodeposition," Materials Letters, Vol. 61, 2007, pp. 2952-2955. doi:10.1016/j.matlet.2006.10.050

[22] B. Viswanath and N. Ravishankar, "Interfacial Reactions in Hydroxyapatite/Alumina Nanocomposites," Scripta Materialia, Vol. 55, 2006, pp. 863-866. doi:10.1016/j.scriptamat.2006.07.049

[23] B. T. Lee, C. W. Lee, A. K. Gain and H. Y. Song, "Microstructures and Material Properties of Fibrous Hap/ $\mathrm{Al}_{2} \mathrm{O}_{3}-\mathrm{ZrO}_{2}$ Composites Fabricated by Multi-Pass Extrusion Process," Journal of European Ceramic Society, Vol. 27, 2007, pp. 157-163. doi:10.1016/j.jeurceramsoc.2006.02.038

[24] J. M. Ten Cate and J. D. B. Featherstone, "Mechanistic Aspects of the Interaction between Fluoride and Dental Enamel," Critical Reviews in Oral Biology and Medicine, Vol. 2, 1991, pp. 283-296. 
[25] C. L. Deal, "Osteoporosis: Prevention, Diagnosis, and Management," American Journal of Medicine, Vol. 102, No. 1A (Supplement), 1997, pp. 35S-9S. doi:10.1016/S0002-9343(97)00415-4

[26] F. Menaa, B. Menaa and O. Sharts, "Fluoro-Raman Spectroscopy as New Analytical Tool for Pharmaceutical and Biomedical Applications," Faraday Discussions, Vol. 149, 2011, pp. 269-278. doi:10.1039/c005252c

[27] L. L. Demos, H. Kazada, F. M. Cicuttini, M. I. Sinclair and C. K. Fairly, "Water Fluoridation, Osteoporosis, Fractures - Recent Developments," Australian Dental Journal, Vol. 46, No. 2, 2001, pp. 80-87. doi:10.1111/j.1834-7819.2001.tb00561.x

[28] F. Ben Ayed, J. Bouaziz and K. Bouzouita, "Pressureless Sintering of Fluorapatite under Oxygen Atmosphere," Journal of European Ceramic Society, Vol. 20, No. 8, 2000, pp. 1069-1067. doi:10.1016/S0955-2219(99)00272-1

[29] F. Ben Ayed, J. Bouaziz and K. Bouzouita, "Calcination and Sintering of Fluorapatite under Argon Atmosphere," Journal of Alloys and Compounds, Vol. 322, No.1-2, 2001, pp. 238-245. doi:10.1016/S0925-8388(01)01200-2

[30] J. C. Heughebaert, “Contribution à L'Étude de L'Évolution des Orthophosphates de Calcium Précipités en Orthophosphates Apatitiques," Thèse, INP, Toulouse, 1977.

[31] G. E. Cootea, R. J. Sparksa and P. Blattnerb, "Nuclear Microprobe Measurement of Fluorine Concentration Profiles, with Application in Archaeology and Geology," Nuclear Instruments Methods, Vol. 197, 1982, pp. 213-221. doi:10.1016/0167-5087(82)90139-9

[32] S. Brunauer, P. H. Emmet and J. Teller, “Absorption of Gases in Multimolecular Layers," Journal of the American Chemical Society, Vol. 60, 1938, pp. 310-319. doi:10.1021/ja01269a023

[33] R. Z. Legeros, "Crystallography Studies of the Carbonate Substitution in the Apatite Structure," PhD thesis, New York University, New York, 1967.

[34] N. Senamaud, D. Bemache-Assollant, E. Champion, M. Heughebaertb and C. Reyb, "Calcination and Sintering of Hydroxyfluorapatite Powders," Solid State Ionics. 101-103, 1997, pp. 1357-1362. doi:10.1016/S0167-2738(97)00242-7

[35] S. Kim, Y. M. Kong, I. S. Lee and H. E. Kim, "Effect of Calcinations of Starting Powder on Mechanical Properties of Hydroxyapatite-Alumina Bioceramic Composite," Journal of Materials Science: Material Medical, Vol. 13, 2002, pp. 307-310. doi:10.1023/A:1014019103240

[36] D. Santhiya, S. Subramanian, K. A. Natarajan and S. G. Malghan, "Surface Chemical Studies on Alumina Suspensions Using Ammonium Poly(Methacrylate)," Colloids and Surfaces A: Physicochemical and Engineering Aspects, Vol. 164, 2000, pp. 143-154. doi:10.1016/S0927-7757(99)00347-7

[37] Y. Chen, S. Liu and G. Wang, "Kinetics and Adsorption Behavior of Carboxymethyl Starch on A-Alumina in Aqueous Medium," Journal of Colloid and Interface Science, Vol. 303, 2006, pp. 380-387. doi:10.1016/j.jcis.2006.08.011

[38] A. Boumaza, L. Favaro, J. Lédion, G. Sattonnay, J. B. Brubach, P.Berthet, A. M. Huntz, P. Roy and R. Tétot, "Transition Alumina Phases Induced by Heat Treatment of Boehmite: An X-Ray Diffraction and Infrared Spectroscopy Study," Journal of Solid State Chemistry, Vol. 182, 2009, pp. 1171-1176. doi:10.1016/j.jssc.2009.02.006

[39] K. A. Bhadang and K. A. Gross, "Influence of Fluorapatite on the Properties of Thermally Sprayed Hydroxyapatite Coatings," Biomaterials, Vol. 25, 2004, pp. 4935-4945. doi:10.1016/j.biomaterials.2004.02.043

[40] M. Hidouri, K. Bouzouita, F. Kooli and I. Khattech, "Thermal Behaviour of Magnesium-Containing Fluorapatite," Materials Chemistry and Physics, Vol. 80, No. 2003, pp. 496-505. doi:10.1016/S0254-0584(02)00553-9

[41] M. Hidouri, K. Bouzouita, A. Aissa and M. Debbabi, "Étude Structurale des Fluorapatites Contenant du Magnésium en Substitution," Comptes Rendus Chimie, Vol. 7, 2004, pp. 699-705. doi:10.1016/j.crci.2004.04.003

[42] K. Chaari, F. Ben Ayed, J. Bouaziz and K. Bouzouita, "Elaboration and Characterization of Fluorapatite Ceramic with Controlled Porosity," Materials Chemistry and Physics, Vol. 113, No.1, 2009, pp. 219-226. doi:10.1016/j.matchemphys.2008.07.079

[43] Z. He and J. Ma, "Constitutive Modeling of Alumina Sintering: Grain-Size Effect on Dominant Densification Mechanism," Computational Materials Science, Vol. 32, 2005, pp. 196-202. doi:10.1016/j.commatsci.2004.08.006

[44] J. F. Roy, M. Descemond, C. Brodhag and F. Thevenot, "Alumina Microstructural Behaviour under Pressureless Sintering and Hot-Pressing," Journal of European Ceramic Society, Vol. 11, 1993, pp. 325-333. doi:10.1016/0955-2219(93)90032-M

[45] P. Quirmbach, M. Wolf and R. J. Brook, "Development of Microstructure during Pressureless Sintering of Alumina," Journal of European Ceramic Society, Vol. 10, 1992, pp. 51-57. doi:10.1016/0955-2219(92)90118-W

[46] M. Azar, P. Palmero, M. Lombardi, V. Garnier, L. Montanaro, G. Fantozzi and J. Chevalier, "Effect of Initial Particle Packing on the Sintering of Nanostructured Transition Alumina," Journal of European Ceramic Society, Vol. 28 2008, pp. 1121-1128. doi:10.1016/j.jeurceramsoc.2007.10.003

[47] H. Fischer, R. Weiß and R. Telle, "Crack Healing in Alumina Bioceramics," Dental Materials, Vol. 24, 2008, pp. 328-332.

[48] X. Teng, H. Liu and Ch. Huang, "Effect of $\mathrm{Al}_{2} \mathrm{O}_{3}$ Particle size on the Mechanical Properties of Alumina-Based Ceramics," Materials Science and Engineering: A, Vol. 452453, 2007, pp. 773-780. doi:10.1016/j.msea.2006.10.073

[49] H. M. Lee, C. Y. Huang and C. J. Wang, "Forming and Sintering Behaviors of Commercial $\alpha-\mathrm{Al}_{2} \mathrm{O}_{3}$ Powders with Different Particle Size Distribution and Agglomeration," Journal of Materials Processing Technology, Vol. 209, No. 2, 2009, pp. 714-722. doi:10.1016/j.jmatprotec.2008.02.047 
[50] N. Louet, H. Reveron and G. Fantozzi, "Sintering Behaviour and Microstructural Evolution of Ultrapure A-Alumina Containing Low Amounts of $\mathrm{SiO}_{2}$," Journal of European Ceramic Society, Vol. 28, 2008, pp. 205-215. doi:10.1016/j.jeurceramsoc.2007.04.015

[51] F. Ben Ayed, "Frittage Et Caractérisation de la Fluorapatite,” Faculté des Sciences de Sfax, 2003.

[52] N. Bouslama, F. Ben Ayed and J. Bouaziz, "Sintering and Mechanical Properties of Tricalcium Phosphate-Fluorapatie Composites," Ceramics International, Vol. 35, 2009, pp. 1909-1917. doi:10.1016/j.ceramint.2008.10.030

[53] F. Ben Ayed and J. Bouaziz, "Sintering of Tricalcium Phosphate-Fluorapatite Composites by Addition of Alumina," Ceramics International, Vol. 34, 2008, pp. 18851892. doi:10.1016/j.ceramint.2007.07.017

[54] H. Ji and P. M. Marquis, "Sintering Behaviour of Hydroxyapatite Reinforced with $20 \mathrm{wt} \% \mathrm{Al}_{2} \mathrm{O}_{3}$," Journal of Materials Science, Vol. 28, 1993, pp. 1941-1945. doi:10.1007/BF00595767

[55] H.Y. Juang and M.H. Hon, "Fabrication and Mechanical Properties of Hydroxyapatite-Alumina Composites," Material Science and Engineering, Vol. 12, 1994, pp. 77-81. doi:10.1016/0928-4931(94),90033-7

[56] D. Asmi, I. M. Low, B. H. O'Connor and C. Buckley, "Phase Compositions and Depth Profiling of Calcium Aluminates in a Functionally-Graded Alumina/Calcium-
Hex-aluminate Composite," Journal of Materials Processing Technology, Vol. 118, 2001, pp. 219-224. doi:10.1016/S0924-0136(01)00963-3

[57] A. Gutiérrez-Alejandre, M. Gonzalez-Crus, M. Trombetta, G. Busca and J. Ramirez, "Chracterisation of Alumina-Titania Mixed Oxide Supports, Part II: $\mathrm{Al}_{2} \mathrm{O}_{3}$-Based Supports," Microp. Mesop. Mat., Vol. 23, 1998, pp. 265275. doi:10.1016/S1387-1811(98)00121-8

[58] G. Del Angel, C. Guzman, A. Bonilia, G. Torres amd J. M, "Padilia, Lanthanum Effect on the Structural Properties of $\gamma-\mathrm{Al}_{2} \mathrm{O}_{3}$ Obtained from Bohemite," Materials Letters, Vol. 59, 2005, pp. 499-502.

[59] K. J. D. MacKenzie, M. SchmuÈcker, M. E. Smith, I. J. F. Poplett and T. Kemmitt, "Evolution of Crystalline Aluminates from Hybrid Gel-derived Precursors Studied by XRD and Multinuclear Solid State MAS NMR IV: Calcium Dialuminate, $\mathrm{CaAl}_{4} \mathrm{O}_{7}$ and Calcium Hexaluminate," Thermochemical Acta, Vol. 363, 2000, pp. 181-188. doi:10.1016/S0040-6031(00)00630-4

[60] B. Lazic, H. Kriiger, V. Kahlenberg, J. Konzett and R. Kaindl, "Incommensurate Structure of $\mathrm{Ca}_{2} \mathrm{Al}_{2} \mathrm{O}_{5}$ at High Temperature-Structure Investigation and Raman Spectroscopy," Acta Crystallographica, 2008, pp. 417-425.

[61] J. M. Poujade, C. Zerbib and D. Serre, "Céramiques dentaires," EMC-Dentisterie, Vol. 1, 2004, pp. 101-117. doi:10.1016/j.emcden.2003.11.002 